\title{
Traditional use of plants as medicine and poison by Tagin and Galo Tribe of Arunachal Pradesh
}

\author{
Tonlong Wangpan*, Jumpee Tasar, Tapi Taka, Jentu Giba, Phongam Tesia, Sumpam Tangjang \\ Department of Botany, Rajiv Gandhi University, Rono Hills, Doimukh, Arunachal Pradesh, India.
}

\section{ARTICLE INFO \\ Received on: 02/04/2019 \\ Accepted on: 23/06/2019 \\ Available online: 01/09/2019}

\section{Key words:}

Poisonous plants, ethnomedicine, indigenous knowledge, Eastern Himalaya.

\begin{abstract}
The tribal communities concealing Arunachal Pradesh, India, uses medicinal plants for treating ailments and poisonous plants for fishing and hunting. The study was conducted with an objective to explore the important medicinal and poisonous plants of the Upper Subansiri district. Data were collected using standard questionnaires and group interviews. The data were analysed to find out the Use value and Fidelity level of the collected medicinal plants. The plants were identified referring various flora and herbaria. A total of 36 plants belonging to 26 families were reported, of which 26 were medicinal and 10 were poisonous plants. Leaves $(53 \%)$ were the most commonly used plant part in herbal therapy, while $33 \%$ of the plants were used in paste form. Among the poisonous plants, score for the harmful part was maximum (36\%) for the whole plant. The commonly observed reactions caused by these plants, include allergy, nausea, itching, fever, and death, in severe cases. According to the quantitative data collected from the informants, medicinal plants Clerodendrum glandulosum (96\%), Ageratum houstonianum (94\%), and Centella asiatica $(92 \%)$ were reported with the highest Fidelity Score. As the villages are situated in the remote hills, most of the rural people of this region still depend on herbs and toxic plants for treatment, hunting, and fishing, respectively. However, biochemical investigation of these traditional medicines may unveil new direction in the modern health care system.
\end{abstract}

\section{INTRODUCTION}

The Eastern Himalayan region is considered as one of the 12th World's biodiversity hotspot (Meyer et al., 2000). The Arunachal Pradesh in Eastern Himalaya encompasses significant vegetation types, and the forest comprises treasured medicinal and aromatic plants (Kaul and Haridassan, 2000), with officially recorded list of more than 500 species having medicinal properties (Khongsai et al., 2011; Sarmah et al., 2000). The land is inhabited by the indigenous people having diversified culture and languages. The state comprises a total of 25 districts and about 28 major tribes with 110 sub-tribes, dominating the land since the time immemorial. These tribes are known for their advanced indigenous knowledge system (Wangpan et al., 2017). Tagin and Galo tribes of this state depend on the bioresources available in the forest for

\section{${ }^{*}$ Corresponding Author}

Tonlong Wangpan, Department of Botany, Rajiv Gandhi University, Rono Hills, Doimukh, Arunachal Pradesh.E-mail: twangpan@gmail.com sustenance. They have been practicing the use of locally accessible medicinal plants of the forest for curing of various ailments. Apart from using it as a medicine, these plants were also found to be used in non-medication practices that includes, spiritual healing therapies, rituals, etc. (WHO, 2002). This medicinal plantsbased traditional knowledge is useful for conservation of cultural traditions and biodiversity as well as for improved community healthcare systems (Wangpan et al., 2016).

Arunachal Pradesh is blessed with rich bioresources and conceals about 500 species of medicinal plants having pharmacological significance, out of which $30 \%$ plants are used as fish poison. Forest based poisonous plants species have been reported to be used by rural dwellers worldwide and are also broadly used by tribal communities of this State. Likewise, the tribal communities harbouring this state use these poisonous plants for fishing and animal hunting. So, in addition to agriculture, fishing and hunting are other part of life for the Tagin and Galo tribes. Arrow poisoning and water poisoning are well-known traditional methods among them to kill the fish and animals. 
The Convention of Biological Diversity emphasizes on conservation the indigenous knowledge systems around the world. The Tagin and Galo tribes of this region use medicinal plants of forests origin in their traditional medication system for treatment of various ailments. Thus, documentation of this traditional knowledge is inevitable to throw light into the field of herbal research and to improve the socio-economic development of the people. So, the study was conducted with an objective to explore, identify and document the ethnobotanically important medicinal and poisonous plants of the Upper Subansiri district of Arunachal Pradesh, India.

\section{MATERIALS AND METHODS}

\section{Study area and ethnicity}

The Upper Subansiri district consists of the four major belts, including the Tagin, Galo, and Nyishi tribes, but the recent geographical boundary and the declaration of the newly established district has separated and put the Nyishi tribe under the Kamle District, named after the Kamle river. Tagin and Galo indigenous communities inhabit the bank of river Subansiri of Arunachal Pradesh. The geographical coordinates of the district was stated as $28.5^{\circ}$ and $28.25^{\circ}$ latitude and $93.15^{\circ}$ and $94.20^{\circ}$ longitudes. The geographical area of the district was 7,032 sq. $\mathrm{km}$ (Fig. 1). The district embrace undulating hilly terrains with an altitude ranged from 1,524 to $2,835 \mathrm{~m}$ above mean sea level. The temperature decreases tremendously on increase of elevation in these terrains, and the climate is very cold throughout the year. The dense forest area of the district yokes the rich biodiversity (Murtem and Chaudhry, 2014).

Tagin, one of the designations of Tani tribes are converged in Daporijo, which is the head quarter of Upper Subansiri district. They are considered to be a Mongoloid origin and were believed to be migrated from Tibet. They are superstitious and still practices, aged old tradition of herbal medicine for curing several diseases/ ailments. Hunting and agriculture is the only mainstay for remote villages, while the shift of occupation may be predicted in the near future.

\section{Field survey and data collection}

Standard methodologies of the field and herbarium techniques was followed (Jain and Rao, 1977). An extensive field survey was performed using questionnaires to know the use of plants in medicinal purpose. For comparative statements, group interview was conducted. The information on the significant of the plant parts in preparation of herbal formulation was also recorded. Nature of ailments was identified with the help of local practitioners. Finally, the local market survey was also carried out to evaluate the commercial viability of these plants. The study comprises 50 informants, of which, 12 were females and rest were males. In present study, the age group of informants was ranged from 35- to 60 -year old. Moreover, $70 \%$ of them were illiterate and actively engaged in agriculture and other allied activities.

The collected samples were identified with consultation of taxonomic literatures, Floras [The Flora of British India (Hooker, 1872-1897), Flora of Assam (Kanjilal et al., 1939)] and Herbaria of Botanical Survey of India (Itanagar). The name of the plants were further verified referring the website http://www.theplantlist.org/

\section{Data analysis}

Use value (UV) was calculated following Phillips and Gentry (1993):

$$
\mathrm{UV}_{\mathrm{i}}=\sum U_{\mathrm{i}} / n
$$

where, $U_{\mathrm{i}}$ is the number of use reports cited by an informant for a particular plant species and $n$ is the total number of informants interviewed during the survey.

In order to know the proportion of informants claiming the use of a plant species for medicinal purpose, Fidelity level (FL) was calculated. The formula used for calculation of Fidelity level was FL $(\%)=\mathrm{Np} / N \times 100$, where, $\mathrm{Np}$ is the informants in total, that are claiming to use a particular plant species in treatment of disease and $N$ is the number of informants that use the plants as medicine (Wangpan et al., 2016).

\section{RESULTS AND DISCUSSION}

All total, 36 plants (of 26 families) were found to be used commonly as medicine and poisons in this region. Herb (47\%) was considered to be the most dominant in this study, which was followed by Shrub (31\%), tree (19\%), and Climber (3\%) (Fig. 2). Plant family Urticaceae was reported with five species, followed

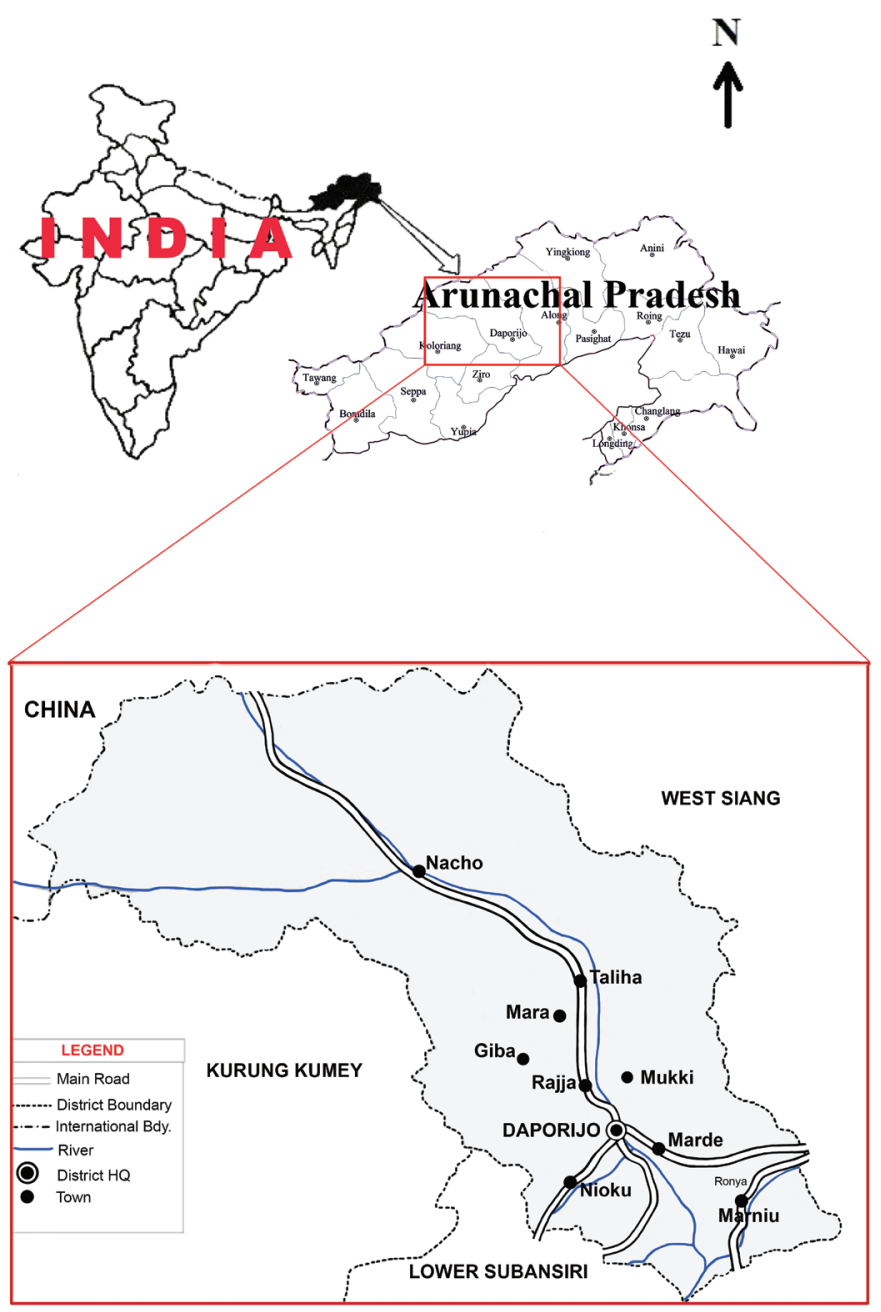

Figure 1. Map of Upper Subansiri District, Arunachal Pradesh (Map not for Scale). 
by Solanaceae and Poaceae with three plant species, Compositae, Polygonaceae, and Zingiberaceae have two species each, while the rest have a single species (Fig. 3). Figure 7 depicts the medicinal and poisonous plants, which were used by Tagin and Galo tribe of Arunachal Pradesh.

\section{Application of plant species as medicines}

A total of 26 plants were reported with the medicinal properties (Table 3). The traditional herbal formulations consists of several plant parts, it includes young twigs, young shoots, rhizomes, leaves, and culm, of which leaves (53\%) was the most preferred plant parts (Fig. 4). Likewise, others also reported the use of fresh leaves, fruits, bark, and stems in preparation of herbal formulation in this region (Goswami et al., 2009).

There were several modes of application of these medicinal plants such as boiled, fermented liquid, juice, paste, powder, raw, smoke, and warm (Fig. 5). However, 33\% of the

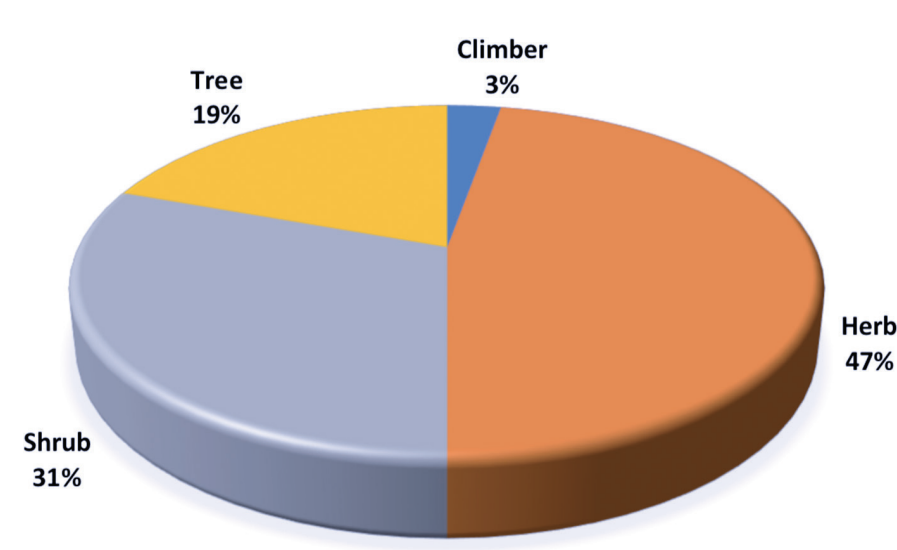

Figure 2. Different habits of the collected medicinal and poisonous plants of Upper Subansiri District, Arunachal Pradesh.

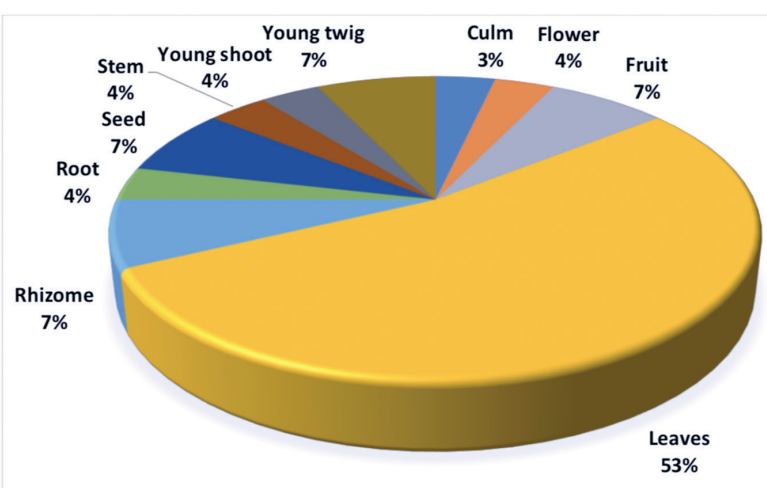

Figure 4. Parts of the collected plants used in medicine among the Galo and Tagin communities in Upper Subansiri district of Arunachal Pradesh.

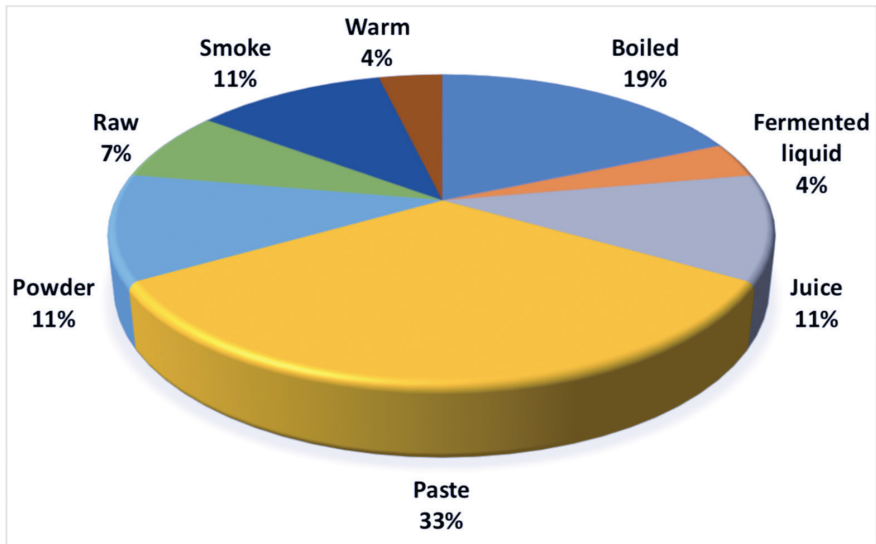

Figure 5. Mode of application of the medicinal plants collected from Upper Subansiri district of Arunachal Pradesh.

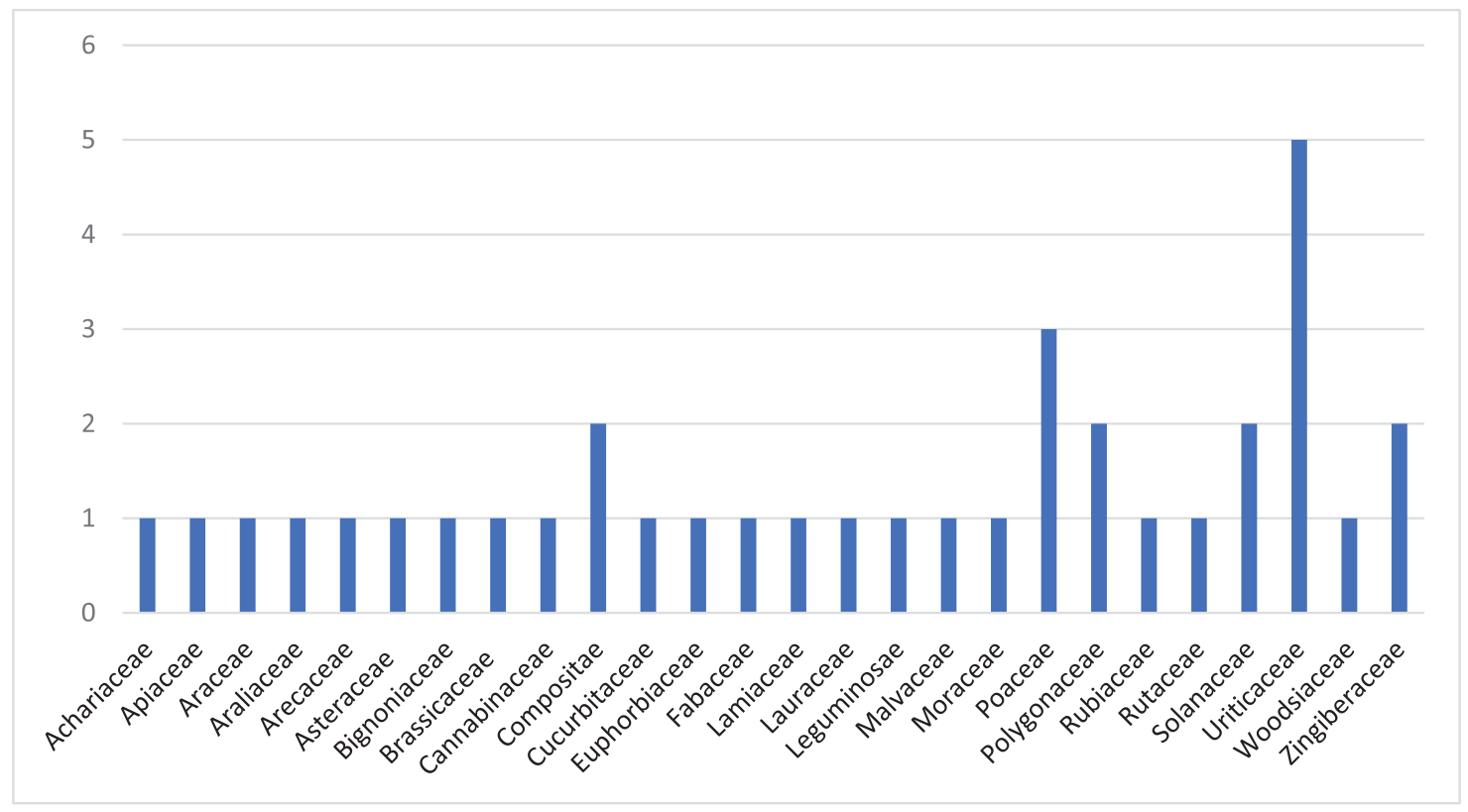

Figure 3. Family distribution of the medicinal and poisonous plants collected from Upper Subansiri District, Arunachal Pradesh. 
plants are applied as a paste. These medicinal plants were very actively used to cure various ailments, including blood pressure, body-ache, burns, cold and cough, constipation, cut and wound, fever, gastrointestinal problems, indigestion, leprosy, malaria, pneumonia, sinusitis, skin diseases, toothache, and urinal tract infection. Some of them were also reported to have anti-maggot, anti-inflammatory, and antibacterial property.

Ethnobotanically, there were several studies reported from the adjacent of this region on utilization of medicinal plants. Vast diversity (more than 50) of herbal medicinal plants used by Apatani, Monpa, Sinpho and Tangsa, Padam, Nyishi, and Mishmi tribes (Khongsai et al., 2011). Recently, a total of 18 plant species was reported from this region to be used as a medicine for the treatment against various ailments. Goswami et al. (2009) reported 10 medicinal plants used by the Traditional Medicinal Practitioner of the Tagin tribe.

According to the quantitative data collected from the informants, Clerodendrum glandulosum (96\%), Ageratum houstonianum (94\%), and Centella asiatica (92\%) were reported with the highest percentage of FL. Plant species A. haustonianum (0.9), C. glandulosum (0.82), and C. asiatica (0.74) were reported with maximum score of UV.

The literatures were not available on the toxic as well as medicinal plants of this district. However, there were several reports on these plants from neighbouring regions of the state. As per previous reports, $C$. asiatica was also reported to be used by Mishmi tribe of the state as medicine against arthritis, diabetes, blood disorders, and brain tonic (Shankar and Rawat, 2008). It is also used in constipation, gastritis, blood purification by Apatani communities of the state (Kala, 2005), and stomach disorder, cuts, wounds, inflammations by Monpas of the state (Namsa et al., 2011). Worldwide, it is not only known for its anti-inflammation potential but also the wound healing property as well (Jin et al., 2004).

Ageratum houstonianum on the other hand, possess antifungal, antimicrobial, and insecticidal properties (Kumar et al.,
2014). Likewise, worldwide, it is known for its Adulticidal activity, antimicrobial activity, and repellent against Culex quinquefasciatus, Aedes aegypti, and Anopheles stephensi (Ravindran et al., 2012; Tennyson et al., 2011; 2012).

Clerodendrum glandulosum has been used in the therapy of hypertension by several tribes of north eastern part of India (Srivastava and Choudhary, 2008). It is also used against Blood pressure, fever, cough by Apatanis of the state (Kala, 2005) and against high blood pressure, stomach disorder, headache by Monpa, and Adi tribe of the state (Chetry et al., 2018; Namsa et al., 2011).

\section{Poisonous plants and their utility}

A total of 10 plant species was reported to be poisonous, of which six plant species (Euphorbia royleana, Litsea polyantha, Ficus microcarpa, Schefflera venulosa, Dendrocnide sinuate, and Girardinia heterophylla) were harmful to Humans, while only four plant species (Zanthoxylum armatum, Athyrium filixfemina, Albizia chinensis, and Gynocardia odorata) were used in fishing (Tables 1 and 2). A total of five different harmful plant parts were recorded, these are barks, fruits, latex, leaves, and the whole plants. In which, maximum active harmful part was the whole plant parts $(36 \%)$, followed by leaves $(22 \%)$, bark $(21 \%)$, fruits (14\%), and latex (7\%) (Fig. 6). There are four different types of reactions caused by poisonous plants of this region, these are allergy, nausea, skin itching, and fever (Table 2), while the most common of these reactions are allergy, nausea, and skin itching.

Similar studies were also done in other parts of Arunachal Pradesh. Recently, about 60 poisonous plants were reported from districts such as, Subansiri, Siang, Anjaw, Dibang Valley, and Kameng districts, and among the plants, Zanthoxylum rhetsa was extensively found to be used in fishing and hunting (Kalita et al., 2017). On the other hand, a total of 21 plants were enlisted to be significant for ethnofisheries among the Nyishi dominated areas of this district (Tag et al., 2005). Also, Adi tribe of this region was reported with the usage of about 28 toxic plants in fishing and hunting (Yumnam and Tripathi, 2013). Gynocardia odorata was

Table 1. Poisonous plant species harmful to Human beings in Upper Subansiri District of Arunachal Pradesh.

\begin{tabular}{|c|c|c|c|c|}
\hline Sl. No. & Scientific name & Harmfulparts & Rating on effectiveness (1-5) & Reactions on contact \\
\hline 1 & Euphorbia royleana Boiss. & Whole plant & 3 & Allergic, nausea and skin itches on being contact with the whole plant. \\
\hline 2 & Litsea polyantha Juss. & Whole plant & 3 & Allergic, nausea and skin itches on being contact with the whole plant. \\
\hline 3 & Ficus microcarpa L. f. & Leaves, Fruits & 3 & $\begin{array}{l}\text { Allergic, nausea and skin itches on being contact with the harmful plant } \\
\text { parts. }\end{array}$ \\
\hline 4 & Schefflera venulosa (Wight \& Arn.) Harms & Leaves, Latex & 2 & Allergic and Skin itches on being contact with the harmful plant parts. \\
\hline 5 & Dendrocnide sinuate (Blume) Chew & Whole plant & 5 & $\begin{array}{l}\text { Allergic, fever and skin Itches for several days on being contact with the } \\
\text { whole plant. }\end{array}$ \\
\hline 6 & Girardinia heterophylla(Vahl) Decne. & Whole plant & 4 & $\begin{array}{l}\text { Allergic and skin itches (for several days) on being contact with the } \\
\text { whole plant. }\end{array}$ \\
\hline
\end{tabular}

Table 2. Poisonous plant species used for fishing in Upper Subansiri District of Arunachal Pradesh.

\begin{tabular}{|c|c|c|c|c|c|}
\hline Sl. No. & Scientific name & Part used & Mode of application/traditional use & $\begin{array}{c}\text { Rating on } \\
\text { effectiveness (1-5) }\end{array}$ & $\begin{array}{l}\text { Dosage/ } \\
\text { duration }\end{array}$ \\
\hline 1 & Zanthoxylum armatum DC. & Fruits, bark & Parts are finely crushed and thrown into stream. & 5 & $15-20$ minutes \\
\hline 2 & Athyrium filix-femina (L.) Roth & Whole plant & Whole plant is ground and thrown into the stream. & 4 & 10-15 minutes \\
\hline 3 & Albizia chinensis (Osbeck) Merr. & Bark & Crushed bark forming red coloured latex is thrown directly into the stream. & 5 & $15-20$ minutes \\
\hline 4 & Gynocardia odorata $\mathrm{R} . \mathrm{Br}$. & Leaves, bark & $\begin{array}{l}\text { Crushed leaves and bark forming white bubbly latex are thrown into the } \\
\text { stream. }\end{array}$ & 4 & 20-25 minutes \\
\hline
\end{tabular}


Table 3. Medicinal plant species used to cure ailments and diseases in Upper Subansiri District of Arunachal Pradesh.

\begin{tabular}{|c|c|c|c|c|c|c|c|}
\hline Sl. No. & Scientific name & Family & Local name & Parts used & Ailments treated and herbal formulation & $\mathbf{U V}$ & FL $(\%)$ \\
\hline 1 & Ageratum houstonianum Mill. & Compositae & Eeh gaarh & $\mathrm{Lv}, \mathrm{Yt}$ & $\begin{array}{l}\text { Paste of leaves and young twigs are applied on wound to stop } \\
\text { bleeding and quick healing }\end{array}$ & 0.82 & 94 \\
\hline 2 & Alocasia acuminata Schott. & Araceae & Pumroh & $\mathrm{Lv}$ & $\begin{array}{l}\text { Paste of leaves are directly applied on the wounds of animals } \\
\text { to relieve from the problems of maggots }\end{array}$ & 0.9 & 56 \\
\hline 3 & Alpinia galanga (L.) Wild. & Zingiberaceae & Pipa & $\mathrm{Rh}$ & $\begin{array}{l}\text { The rhizome is an antibacterial agent and is used during } \\
\text { constipation. }\end{array}$ & 0.74 & 60 \\
\hline 4 & Bambusa balcooa Roxb. & Poaceae & Eeh eneeh & $\mathrm{C}$ & $\begin{array}{l}\text { Paste of culm are applied directly on wound for immediate } \\
\text { blood clotting }\end{array}$ & 0.72 & 30 \\
\hline 5 & $\begin{array}{l}\text { Dendrocalamus hamiltonii Nees \& } \\
\text { Arn. ex Munro. }\end{array}$ & Poaceae & eepom & Ys & $\begin{array}{l}\text { The liquid of fermented young bamboo shoots are used } \\
\text { against bee bite and have anti-inflammatory property }\end{array}$ & 0.66 & 38 \\
\hline 6 & Brassica juncea (L.) Czern. & Brassicaceae & Petto & $\mathrm{Sd}$ & $\begin{array}{l}\text { Seed are bitter in taste and used in digestive problem. The } \\
\text { seed paste is applied to the person for relief in mild fever or } \\
\text { headache; the leaves are edible as vegetable. }\end{array}$ & 0.78 & 32 \\
\hline 7 & Cannabis sativa $\mathrm{L}$. & Cannabinaceae & Bhang & $\mathrm{Lf} \& \mathrm{Sd}$ & $\begin{array}{l}\text { Dry leaves are taken as smoking cigarette for relieving body } \\
\text { pain; a pinch of seed powder is used in dysentery, diarrhoea. }\end{array}$ & 0.56 & 78 \\
\hline 8 & Centella asiatica (L.) Urb. & Apiaceae & Kedoh keroh & $\mathrm{Lv}$ & $\begin{array}{l}\text { The leaves are warm on fire and applied on ringworm affected } \\
\text { areas }\end{array}$ & 0.46 & 92 \\
\hline 9 & $\begin{array}{l}\text { Chromolaena odorata (L.) } \\
\text { R.M.King \& H.Rob. }\end{array}$ & Compositae & Eeneh pudeh & $\mathrm{Lv}$ & Paste of leaves are directly applied on cut and wounds & 0.44 & 40 \\
\hline 10 & Clerodendrum glandulosum Lindl. & Lamiaceae & Taapin & Lv & $\begin{array}{l}\text { Leaves, young twigs used as vegetables to treat low blood } \\
\text { pressure }\end{array}$ & 0.4 & 96 \\
\hline 11 & Cucumis sativus L. & Cucurbitaceae & Meku & Lf & $\begin{array}{l}\text { The leaf juice is given orally to children during stomach } \\
\text { disorder. It is mainly used as wormicide. The fleshy fruit is } \\
\text { edible and is used to cure indigestion. }\end{array}$ & 0.48 & 90 \\
\hline 12 & Desmodium gyroides (Link) DC. & Fabaceae & Kejo keyo & Lf & $\begin{array}{l}\text { The leaf is burned and the steam is inhaled when sinusitis } \\
\text { occurs; the fresh leaf juice is used against leprosy and related } \\
\text { skin diseases. }\end{array}$ & 0.62 & 86 \\
\hline 13 & Imperata cylindrica (L.) Raeusch. & Poaceae & Madoli & $\mathrm{Ft}$ & $\begin{array}{l}\text { The powdered dry fruits is applied on freshly cut and wound } \\
\text { for immediate blood clotting. }\end{array}$ & 0.82 & 58 \\
\hline 14 & Microsorum punctatum (L.) Copel. & Polypodiaceae & Dogum moruh & Lv & paste of leaves have anti-inflammatory properties & 0.4 & 52 \\
\hline 15 & Mussaenda roxburghii Hook. f. & Rubiaceae & Taksap & Lf & $\begin{array}{l}\text { The leaf paste is applied to freshly cut wound in order to } \\
\text { enable blood clotting; and it is also edible as vegetable. }\end{array}$ & 0.38 & 44 \\
\hline 16 & Polygonum chinense $\mathrm{L}$. & Polygonaceae & Donyi magbo & Lf & $\begin{array}{l}\text { The leaves are boiled and taken during urination problem, and } \\
\text { it is edible as vegetable. }\end{array}$ & 0.38 & 76 \\
\hline 17 & $\begin{array}{l}\text { Rhaphidophora decursiva (Roxb.) } \\
\text { Schott. }\end{array}$ & Arecaceae & Tarr lome & St & $\begin{array}{l}\text { The fresh paste of stem is used in cut and wound, and also in } \\
\text { fire burn area. }\end{array}$ & 0.38 & 54 \\
\hline 18 & Sarcochlamys pulcherrima Gaudich. & Uriticaceae & Osik & Lf & $\begin{array}{l}\text { The boiled leaves are consumed to cure constipation, and it is } \\
\text { also applied to cut and wounds for quick healing. }\end{array}$ & 0.36 & 44 \\
\hline 19 & Solanum nigrum $\mathrm{L}$. & Solanaceae & Oryange & Lf & $\begin{array}{l}\text { The powdered dry leaves are used in the treatment of malaria. } \\
\text { The fresh leaves are boiled and juice is taken during gastritis } \\
\text { problem and in constipation. }\end{array}$ & 0.36 & 56 \\
\hline 20 & Solanum viarum Dunal. & Solanaceae & Al tao & $\mathrm{Ft}$ & $\begin{array}{l}\text { The smoke of burn fruit is sucked through a pipe made of } \\
\text { bamboo and retained the smoke in mouth to expel tooth worm } \\
\text { from the tooth. }\end{array}$ & 0.32 & 24 \\
\hline 21 & Acmella oleracea (L.) R.K. Jansen & Asteraceae & Marsa & $\mathrm{Fr}$ & $\begin{array}{l}\text { The fresh flower is used in the treatment of toothache and the } \\
\text { leaves are edible as vegetable }\end{array}$ & 0.28 & 54 \\
\hline 22 & $\begin{array}{l}\text { Stereospermum colais (Buch.-Ham. } \\
\text { ex Dillwyn) Mabb. }\end{array}$ & Bignoniaceae & Maneeh seenh & $\mathrm{Yt}$ & paste of young twig are used against backbone pain & 0.28 & 58 \\
\hline 23 & Urena lobata $(\mathrm{L})$. & Malvaceae & Tagam bayom & Rt & $\begin{array}{l}\text { The juice extract of root and paste is used in the treatment of } \\
\text { malarial fever and pneumonia. }\end{array}$ & 0.24 & 8 \\
\hline 24 & Urtica palmata Forssk. & Urticaceae & Poso & Lf & The leaves are boiled, used in bathing to cure skin itching. & 0.24 & 64 \\
\hline 25 & Urtica pulcherrima Roxb. & Urticaceae & Ombe & Lf & The leaves are boiled and taken during constipation. & 0.18 & 64 \\
\hline 26 & Zingiber officinale Roscoe. & Zingiberaceae & Takeeh & $\mathrm{Rh}$ & $\begin{array}{l}\text { Rhizomes are consumed raw or cooked for immediate cure } \\
\text { from cough and cold. }\end{array}$ & 0.08 & 57 \\
\hline
\end{tabular}




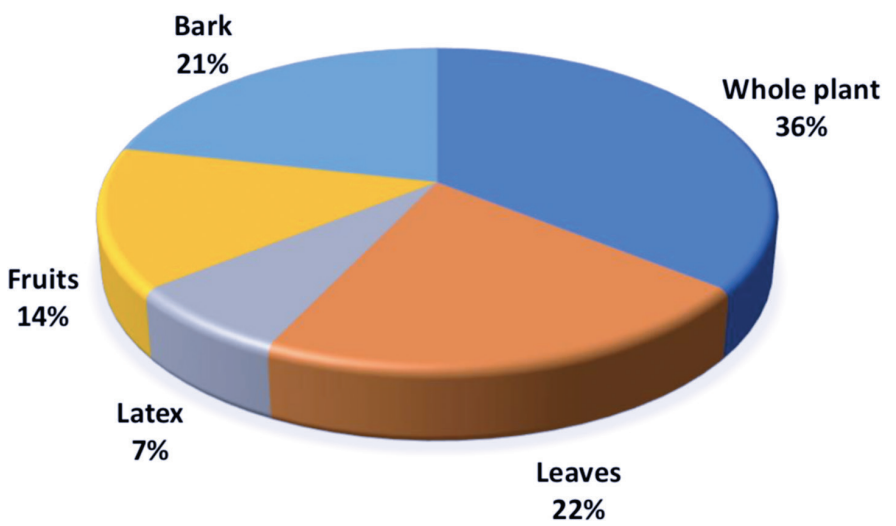

Figure 6. Harmful parts of poisonous plants of Upper Subansiri District, Arunachal Pradesh.
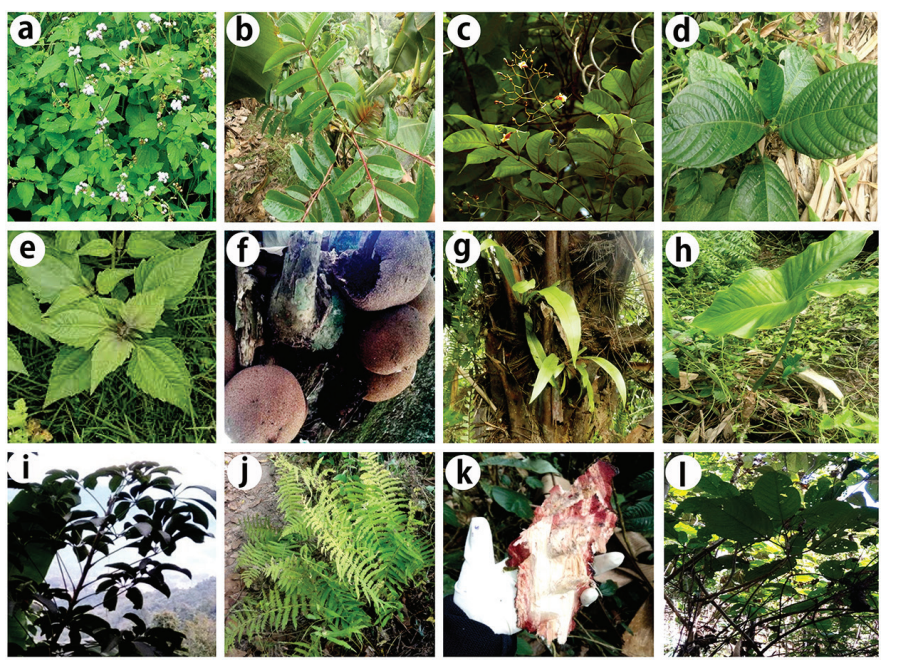

Figure 7. Some of the medicinal and poisonous plants used by Tagin and Galo tribe of Upper Subansiri district of Arunachal Pradesh: (a) Ageratum houstonianum, (b) Zanthoxylum armatum, (c) Stereospermum colabis, (d) Dendrocnide sinuate, (e) Chromolaena odorata, (f) Gynocardia odorata, (g) Microsorum punctatum, (h) Alocasia acuminate, (i) Schefflera venulosa, (j) Athyrium filix-femina, (k) Albizia chinensis, and (l) Litsea polyantha.

also used by Nyishi tribe of the state for fishing (Tag et al., 2005). Likewise, plant species $Z$. armatum and A. chinensis was also reported to be used by Adi tribe of the state for fishing (Yumnam and Tripathi, 2013).

\section{CONCLUSION}

The present study among the two tribes of Arunachal Pradesh records a decent number of medicinal as well as poisonous plants. The study also reveals the exitance of traditional knowledge among the tribal community. The locals were depending on these herbs for the treatment of various human and livestock related diseases. Poisonous plants, on the other hand, were used for hunting and fishing, thereby, providing required nutrients for subsistence. However, investigation of biochemical, followed by clinical trials of these herbs may offer a new direction. So, there is a utter need of constant effort and intervention of scientific community and policy maker as well, for further researches, on the ethno-medicobotanical knowledge before it is lost in the wreckages of modernization.

\section{ACKNOWLEDGEMENTS}

The authors would like to thank the Tagin and Galo tribal community of Upper Subansiri district of Arunachal Pradesh for sharing their valuable knowledge with us.

\section{CONFLICT OF INTEREST}

The authors declare that this paper content has no conflict of interest.

\section{REFERENCES}

Chetry LB, Basar K, Taye K, Taka T, Tsering J, Wangpan T. Medicinal plants used against gastrointestinal disorders among the Adi Tribe of Eastern Himalaya. Nebio, 2018; 9(1):93-101.

Goswami P, Soki D, Jaishi A, Das M, Sarma HN. Traditional healthcare practices among the Tagin tribe of Arunachal Pradesh. Indian J Tradit Know, 2009; 8(1):127-30.

Hooker JD. The Flora of British India, vol. 1-7. Reeve \& Co. Ltd., London, 1872-1897.

Jain SK, Rao RR. A handbook of field and herbarium methods. Today and Tomorrow's Printers and Publishers, New Delhi, India, 1977.

Jin SG, Chuen LC, Koo MWL. Inhibitory effects of Centalla asiatica water extract and asiaticoside on inducible nitric oxide synthase during gastric ulcer healing in rats. Plant Medica, 2004; 70:1150-4.

Kala CP, Ethnomedicinal botany of the Apatani in the Estern Himalayan region of india. J Ethnobiol Ethnomed, 2005; 1:11.

Kalita BC, Tag H, Gogoi BJ, Hui PK. Diversity and traditional uses of some poisonous plants of Arunachal Pradesh. Int J Adv Res Innov Ideas Educ, 2017; 3(1):755-763.

Kanjilal UN, Das A, Kanjilal PC, De RN. Flora of Assam, vol. 3. Government of Assam, Shillong, 1939.

Kaul RN, Haridassan K. Forest types of Arunachal Pradesh, A preliminary study. J Econ Tax Bot, 2000; 9(2):379-89.

Khongsai M, Saikia SP, Kayang H. Ethnomedicinal plants used by different tribes of Arunachal Pradesh. Indian J Tradit Know, 2011; 10(3):541-6.

Kumar, N. Biological potential of a weed Ageratum houstonianum Mill: a review. Indo Am J Pharm Res, 2014; 4:2683-9.

Meyer N, Mittermeier RA, Fonseca GAB, Kent J. Biodiversity hotspots for conservation priorities. Nature, 2000; 3(24):853-8.

Murtem G, Chaudhry P. Sacred Groves of Arunachal Pradesh: traditional way of biodiversity conservation in Eastern Himalaya of India. J Biodivers Manag Forestry, 2014; 3:2:1-14. doi:10.4172/2327-4417.10001

Namsa ND, Mandal M, Tangjang S, Mandal SC. Ethnobotany of the Monpa ethnic group at Arunachal Pradesh, India. J Ethnobiol Ethnomed, 2011; 14:7-31. doi: 10.1186/1746-4269-7-31.

Phillips O, Gentry AH. The useful plants of Tambopata, Peru: I. Statistical hypotheses tests with a new quantitative technique. Econ Bot, 1993; 47:15-32.

Ravindran J, Samuel T, Alex E, William J. Adulticidal activity of Ageratum houstonianum Mill. (Asteraceae) leaf extracts against three vector mosquito species (Diptera: Culicidae). Asian Pac J Trop Dis, 2012; 2(3):177-9.

Sarmah A, Haridasan K, Bisht NS. Development of medicinal plants and economic venture of in Arunachal Pradesh, prospects and constraints. Arunachal For News, 2000; 18(1\&2):85-90.

Shankar R, Rawat VK. Medicinal plants used in traditional medicine in Lohit and Dibang valley districts of Arunachal Pradesh. Indian J Tradit Knowl, 2008; 7(2):288-95.

Srivastava RC, Choudhary RK. Species diversity and Economic importance of the family Verbenaceae in Arunachal Pradesh. Bull Arunachal For Res, 2008; 24(1\&2):1-21. 
Tag H, Das A K, Kalita P. Plants used by the Hill Miri tribe of Arunachal Pradesh in ethnofisheries. Indian J Tradit Knowl, 2005; 4(1): $57-64$.

Tennyson S, Ravindran J, Eapen A, William A. Repellent activity of Ageratum houstonianum Mill. (Asteraceae) leaf extracts against Anopheles stephensi, Aedes aegypti and Culex quinquefasciatus (Diptera: Culicidae). Asian Pac J Trop Dis, 2012; 2(6):478-80.

Tennyson S, Balaraju K, Park K, Raja AK, Ravindran K J, Eapen A, William SJ. In vitro antimicrobial activity of Ageratum houstonianum Mill. (Asteraceae). Elixir Food Sci, 2011; 35:2897-900.

Wangpan T, Chetry LB, Tsering J, Taka T, Tangjang S. Antimalarial plants of Jonai, India: an ethnobotanical approach. Notulae Sci Biol, 2016; 8:27-32. doi:10.15835/nsb.8.1.9750.

Wangpan T, Tangjang S, Arunachalam A. Tribal agriculture: tradition in transition in the Indian Eastern Himalaya. Curr Sci, 2017; 112(7):1327-9.
World Health Organisation. (2002) Traditional medicine strategy (2002-2005). WHO, Geneva, Switzerland.

Yumnam JY, Tripathi OP. Ethnobotany: plants use in fishing and hunting by Adi tribe of Arunachal Pradesh. Indian J Tradit Knowl, 2013; 12(1):157-61.

\section{How to cite this article:}

Wangpan T, Tasar J, Taka T, Giba J, Tesia P, Tangjang S. Traditional use of plants as medicine and poison by Tagin and Galo Tribe of Arunachal Pradesh. J Appl Pharm Sci, 2019; 9(09):098-104. 